\section{Effect of an Anzesthetic on the Heart and Respiration of Teleost Fish}

THE properties of Sandoz 'M.S. 222' compound, a meta-amino-benzoic acid ethyl ester in the form of a soluble salt, as a general anæsthetic ${ }^{1,2}$ have led to its widespread use in studies of fish physiology. The general effects of this, and other anæsthetics on fish, have been examined by $\mathrm{McFarland}^{3}$, but, in the course of experiments on some aspects of the respiratory and circulatory physiology of teleosts, it became clear that ' $M . S$. 222' caused changes of considerable significance not hitherto described.

In these experiments the eloctrocardiogram, respiratory rate, and respiratory amplitude wero rocorded in tench (Tinca tinca, L.) held in a tank of $1,750 \mathrm{ml}$. capacity. Handling the fish caused a considerable rise in the heart-rate, ofton to three times the value found in a fish that had remained inactive and undisturbed in the tank for periods of more than $1 \mathrm{hr}$. The usual range of heart-rate in an undisturbed tench was found to be $15-30$ beats $/ \mathrm{min}$. When the heartrate had reached this resting value, a known concentra. tion of 'M.S. 222' was passed through the tank for periods up to $90 \mathrm{~min}$. in duration. Six concentrations of the anesthetic were used, 25-200 mgm./1., and the experiments were carried out on 15 fish weighing 38-144 gm.

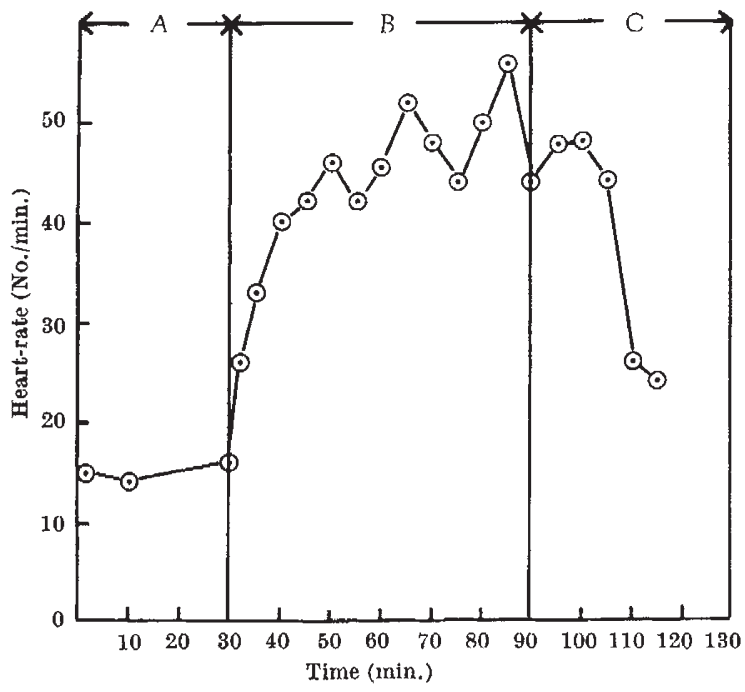

Fig. 1. Effect of 'M.S.222' on the heart-rate of a 57 -gm. tench
(temperature, $17^{\circ}$ C.). $A$, Fresh water; B, 'M.S.222' 33 mgm./l' (temperature, $17^{\circ}$ C.). $A$, Freshwater; $B$, 'M.S.222' 33 mgm./l.;

The effect of 'M.S. 222 ' was to produce an increase in heart-rate (Fig. 1), the increase being more marked at higher concentrations. The respiratory-rate and amplitude were also increased, though in a somewhat variable way as the relationship between these two parameters of the broathing movernent is complex. 'M.S. 222' probably acts on the heart via the parasympathetic nervous system (there being no sympathetic innervation) since the direct effoct of the substance on the isolated and perfused hearts of tench, trout and roach was to decrease the frequoncy of beat. This conclusion was substantiated when it was found that 'M.S. 222' in tho ventilation stream of a tench in which the tenth vagi had been sectioned bilaterally resulted in a decrease in the animal's heart-rate.

The increase in heart-rate cuused by 'M.S. 222' in the intact animal was paralleled by a simultan- eous increase in respiratory rate and, though there was no strict correlation between the heart beat and any part of the respiratory cycle, it is suggested that some connexion exists between cardiac and respiratory control systems within the brain. In concentrations of 100-200 $\mathrm{mgm} . / 1$. ' $M . S .222$ ' respiratory collapse was common, the breathing becoming irregular and ultimately stopping. Simultaneously the heartbeat would also become irregular and the frequency would fall. Recovery in the breathing was always accompanied by a similar rocovery in tho regularity and frequency of the heart beat.

Department of Zoology,

D. J. Randali

The University,

Southampton.

${ }^{1}$ Gilbert, P. W., and Wood, N. (t., Science, 126, 212 (1957).

${ }^{2}$ Bull, J. N., and Cowan, P. N., Nature, 184, 370 (1959).

${ }^{3}$ Meliarland, W. N., Pub. Inst. Mar, Sci. Uniw. Tex, 6, 23 (1959).

\section{Effects of Mammalian Growth Hormone on Cottus scorpius Blood}

IT is now well established that the teleost pituitary contains a growth-promoting hormone, the evidence coming from injection of fish pituitary preparations and from tho offects of hypophysectomy ${ }^{1}$. Although growth effects have been studied, the metabolic responses of either fish or mammalian sornatotrophin in teleosts, such as possiblo diabetogenic action, havo not been investigated. Both the nitrogen retention and diabetogenic effects of somatotrophin in mammals are well known and it has now been shown during work on hypophysis-pancreas relations in teleost fish that mammalian growth hormone affects blood glucose, protein and urea in Cottus scorpius.

Armour 'Somar $A$ ' was injected intraperitoneally into twelve Cotlus scorpius weighing $300-500 \mathrm{gm}$. at a l mgm./kgm. dose-level every third day for fifteen days. Blood was obtained from the ductus Cuvieri running subcutaneously immediately beneath the operculum and blood sugar determined spectrophotometrically by a glucose oxidase method ('Blutzucker Farb-'Test', Biochemica Boehringer). The blood glucose, determined every third day for ten days prior to growth hormono, was $6 \cdot 6 \pm S \cdot F \cdot 0 \cdot 34 \mathrm{mgm}$. $100 \mathrm{ml}$. blood. There was no rise in blood sugar for the first three days after injection of 'Somar $A$ ', but within six days tho blood glucose-level had risen to $12.6 \pm S . E .1 .11 \mathrm{mgm} . / 100 \mathrm{ml}$. This marked elevation of blood glucose was maintained for the duration of the injections. This effect is in contrast to fish growth hormone injections, which exert no metabolic effect in mammals (nitrogen retention, cardiac glycogen $)^{2}$ and to experiments which indicate that hypophysectomy of Cottus scorpius does not result in any lowering of blood glucose-levels over a period of a month ${ }^{3}$.

After fifteen days, blood samples of the growth hormone treated fish were taken and the plasma total protein, urea and amino-acid nitrogen determined by biuret, urease-nosslerization and $\beta$-naphthoquinone4-sulphonate methods respectively. The total plasma protein of the treated fish was lowered, being 24.5 mgm. \pm S.E. $2 \cdot 45 / \mathrm{ml}$. compared with an untreated fish value of $34 \cdot 1 \mathrm{mgm}$. $\pm S . E .1 \cdot 79 / \mathrm{ml}$. The plasma urea was also reduced to $65 \cdot 8 \mu \mathrm{gm}$. $\pm S . E .5 \cdot 32 / \mathrm{ml}$. plasma compared with untreated fish of $109.0 \mu \mathrm{gm}$. \pm S.E. $14 \cdot 5 / \mathrm{ml}$. plasma. The nitrogen retention effect of mammalian growth hormone on fish is thus 